\title{
IDENTITY AND INHERITANCE KHAP THUM LUANG PRABANG OF LAOTIAN DIASPORA IN CHIANG RAI THAILAND
}

\author{
Sapanna Kaewtapee \\ Ph.D. Candidate (Education), Faculty of Education, Chiang Mai University, Thailand \\ DOI: 10.46609/IJSSER.2021.v06i02.010 URL: https://doi.org/10.46609/IJSSER.2021.v06i02.010
}

\section{ABSTRACT}

This research article is the objective is to study the succession guidelines, how to conserve and develop "Khap Thum Luang Prabang" in Ban Huay Luek Community, Wiang Kaen District, Chiang Rai Province. This study presents a critical analysis of the factors that make Laotian diaspora in Ban Huay Luek Community, Wiang Kaen District, Chiang Rai Province Thailand, and study the identity and persistence of Laotian Diaspora via Khap Thum Luang Prabang in Ban Huay Luek Community Wiang Kaen District Chiang Rai Thailand. That still inherits and preserves Khap Thum Luang Prabang, it begins by reviewing documents and books about various types of folk music. Then went to the area to study the music and interview those who participated in the singing, as well as recording the performance, to analyze and interpret the story about the nature of the song, the characteristics of the music are unique to the Laotian diaspora in Thailand. The factors that make their culture have been inherited to the present day, although they have long migrated to Thailand. However, the music also connects the culture of Laos Luang Prabang and the Laotian diaspora. This is a reflection of the roots and remembrance of their homeland, which can tell the history and reflect their identity as a unique Lao Luang Prabang ethnic. However, it was found that the succession guidelines on how to conserve and develop Khap Thum Luang Prabang in Ban Huay Luek community, Wiang Kaen district, Chiang Rai province, is mainly used in the general merit of the village tradition. This, Khap Thum Luang Prabang, communicates ethnicity in addition to the Lao spoken language, and the dress is a characteristic of Laos. The culture of tradition is also unique to the Lao ethnic group. Khap Thum Luang Prabang is also a representative of the brotherhood relationship between the Lao diaspora in Thailand and the Laos people. The factors that make their culture have been inherited to the present day. Although they migrated to Thailand a long time ago, the music still connects the cultures of Laos Luang Prabang and Laotian diaspora. Reflection of roots and remembrance of their homeland, they can tell their history and reflect their identity as a unique Laos Luang Prabang ethnicity, it was found to be via Khap Thum Luang Prabang of Laotian diaspora, the first and second generations are still going continuously, but in the third generation, succession 


\section{International Journal of Social Science and Economic Research}

ISSN: $2455-8834$

Volume:06, Issue:02 "February 2021"

began to shake and there was no successor because the third generation sequence has no living memories of the homeland of Laos's people.

Keywords:Identity, Inheritance, Khap Thum Luang Prabang, Laotian Diaspora

\section{Introduction}

"Khap Thum Luang Prabang" is a play for the enjoyment of Lao people in Laos, there is a culture of "Khap" in the north from Wiang Chan upwards. It is commonly seen in merit festivals or when meeting for various occasions in each city in northern Laos. It has an accent and a typical driving melody of each local own. However, the center of "Khap" culture is in Luang Prabang, which was the old capital of Laos since it was the main culture of the capital city before with various subways in the surroundings, sub-districts of Kwang Bokaew, Luang Namtha, Pongsali, Udomchai, Sam Nuea, Xieng Khouang, Wiang Chan, Sai Buri, and Ban Huay Luek. Authentic Khap Thum identity $t$ is the use of xylophone as a masterpiece of Lao music; Lao people call it "Nang Nad Ek", "Nang Nad Thum", and use a gong together because royal music is so focused on percussion music. Therefore, Luang Prabang music is influenced by this type of music (Chalermsak Pikulsri, 2009). In the north of Laos, the border with northern Thailand is Chiang Saen, Chiang Khong district, and Wiang Kaen district, Chiang Rai province. The culture of the Lao community throughout the Mekong side of Thailand is constantly flowing. The Lao people who migrated to the Thai side also received Khap Thum Luang Prabang.

In 2014, the company moved to Laos and interviewed Laos's people at Ban Huay Luek, Wiang Kaen district, Chiang Rai province, which originally lived in Luang Prabang and Udomchai provinces. The main cause of the evacuation of Laos's people, Ban Huay luek, came from the politics of Laos. The main event affecting the exodus was that the Laos ethnicity had fallen under the French colony since 1893. In this regard, economic development has failed because there is no budget to manage the country. The colonial government can only raise enough money to pay the salaries of civil servants, but there is no budget for other developments, such as building roads, schools, hospitals, and general farming is only for livelihoods. And in 1995, according to an agreement between France and The King of Luang Prabang that came into force across Laos. As a result, Laos's people and the Kha people will have to pay taxes and must be enlisted, and the French also allows lower-level bureaucrats to collect one-tenth of their levy, but there is information that the tax has been more than the allowed amount. When the Lao revolution occurred in the year 1965, there was a political conflict in Laos, causing multiple coups of America's contribution to internal politics. In addition to expanding the influence of the communist side, it took power in 1975, causing many Laos people to flee the country (Grant Evan, 2006). For the above reasons, some Lao Luang Prabang people have migrated across the Mekong River to Thailand. Many times in the border area along the Mekong River, either on the 


\section{International Journal of Social Science and Economic Research}

ISSN: $2455-8834$

Volume:06, Issue:02 "February 2021"

side of Chiang Khong district, Chiang Saen district, or entering Wiang Kaen district. This makes Laos people spread widely in Chiang Rai province, the crossing of these Laos people are walking across the Luang Prabang ridge, and crossing the Mekong River into.

Ban Huay Luek, Wiang Kaen district, Chiang Rai province, is another village with a group of Laos people who emigrated from Laos, which the first time they were gathered at Ban Kon Kham, Muang Yai subdistrict, Wiang Kaen district, Chiang Rai province, which is approximately 7 kilometers from Ban Huay Luek, in the area above Kaeng Pha Dai. But later moved to Ban Huay Luek in 1957, Ban Huai Luek was originally called in the language used by the village people as "Hong Luek" with a very deep creek beside the village. Therefore is the origin of the village name, the word "Hong", refers to a trench, a passage of water that is smaller than a creek, the word "Luek" means "deep". Therefore, the two words combined are meant to be "very deep grooves", but people in neighboring communities who are northerners or Tai-yuan people call it "Huay Luek". It is called "Luek" according to the name of the government village to the present day (Ranida Pingmuang, 2010).

On the entry of immigrants or immigrants, the main obstacles to new arrivals or immigrants must find two things; the first is the state in the form of government officials, who conduct intensive surveillance in the border area because it is a secure area of the state. The second is that residents of the group are ethnic groups of different cultures, the migrants are seen as newcomers, and the right to interact with space is less than those who come in first. (Soonthorn Pasuch, 1971) The state's use of state power to protect the border area gives the state the power of the cross-border and the power of those who have lived before. It is a different ethnic group, but over time it becomes familiar to the area. Negotiating power will come to an all-time high. By creating a cultural capital (Culture Capital) is the identity of each ethnic group that makes it a tool for negotiating with the state for tourism policy. It is also possible to educate people in the Huay Luek area, become a social capital development for the area, and also to generate tourism revenue for the state from the aforementioned capital. This suggests that the state began to use citizen multicultural ship as a bargaining tool for the benefits that the state would have with the ethnic diaspora ethnic group that expressed its identity in Ban Huay Luek district, Wiang Kaen district, Chiang Rai province. As can be seen from the important merit-making or festival in the village, the aforementioned ethnic group identity will be displayed.

Thus, the representation of ethnic identities outside the national boundary or the land of the borders of the ethnicity with fluid-scapes characteristics, it is evident that when people move across the border, they move the culture. For example, the expression of ethnic identity of the Laos diaspora in Chiang Rai through music culture, which is based on the study of the Mekong ethnic group in Chiang Rai province. It was found that Laos's ethnic groups were scattered in Chiang Saen district, Chiang Khong district, and Wiang Kaen districts in Chiang Rai province 


\section{International Journal of Social Science and Economic Research}

ISSN: 2455-8834

Volume:06, Issue:02 "February 2021"

are many. The researcher has seen many forms of ethnic Laos's music culture such as music playing culture. For example the band bpaat-kong-ban-sa-det, Khap Thum Ban Pak Ing, Khap Thum Ban Sop Kam, and Khap Thum Ban Huay Luek, was the last village on the Mekong River on the Thai side before the Mekong River re-entered Laos. In the past, the national line lines were unclear, people on the Thai-Laos Mekong coast are constantly crossing borders and interacting as a culture and sharing resources.

"Khap Thum Luang Prabang" is found in various festivals, including merit and social gatherings. For example, the merit boat race will be held on both the Thai and Lao side of the party, it's fun and friendly. Also, Ban Huay Luek has a typical Khap Thum, such as relaxation, whose feature is the use of gentle language, and Khap Thum is mainly lovemaking between a woman and a man, and the lyrics were thought up fresh Interact with the flair of the people at Khap Thum. However, Khap Thum the difference between the instruments in the play is that there is no xylophone. In this regard, the Khap Thum identity is the one that sings to change with the other side, and how the other will react and end up feeling the rhyme.

However, from Laos Luang Prabang to Laos Ban Huay Luek, the ethnic identity of Laos Luang Prabang of the Lao people of Ban Huay Luek is still passed down and survives today. The process of establishing the ethnic identity of Lao people Ban Huay Luek is associated with the historical, ethnic, social, and cultural dimensions of Luang Prabang through activities, rituals, traditions, and Music. Having a social space to express or choose to bring up a musical identity like Khap Thum Luang Prabang is a hallmark of the community, creating a system of value of identity at an individual and group level. Also, Khap Thum is a sensational welder of Laos Luang Prabang, the process of establishing an identity as a displaced Lao people, having to disperse, relocate, and feel unfamiliar with the territory. There's also a feeling of wanting to go back to their motherland because there's also a common language and culture (William Safran, 1999).

There is one notable thing about the presence of ethnic identity in Khap Thum Luang Prabang, it's constantly changing, blending, and fluid. For example, singing in a deep bass the Lao people of Ban Sop Kham brought a banjo player to play Khap Thum, and in the Lao people, Ban Huay Luek does not have a xylophone, which is the main bachelor of the Lao music band, using fiddle, drum and hit the gong. There is a distinction between Khap Thum Luang Prabang, which plays in the bureaucracy, and the royal court, which will have a huge xylophone. However, the play in the traditions at Ban Sop Kham is no longer available for teaching in the temple, and Ban Pak Ing is no longer Khap Thum at present. The part of Ban Huay Luek still plays an important tradition, and play in daily life when socializing the lyrics and melodies in Khap Thum are different from the Luang Prabang manuscript. It is evident that the social and power relationships that displaced Lao people choose to express ethnic identities. Amid a new context that surrounds 
International Journal of Social Science and Economic Research

ISSN: 2455-8834

Volume:06, Issue:02 "February 2021"

the society of the city and the different cultures in the neighborhood, it is a social operation, and there is a process to determine the position of the person in the Laotian diaspora and to bind the group and the yearning for Lao Luang Prabang of the people of Huay Luek village. Therefore, the identity of Laos Luang Prabang of the people of Huay Luek village is an active identity that seeks to frame their identity at a standstill and death by clashing with Khap Thum Luang Prabang, in a more expansive and diverse identity space, the company has a wide range of identities, it is also possible to select and blend and confirm identity in many different ways and different situations.

\section{Research Objectives}

1. To study the succession guidelines, how to conserve and develop "Khap Thum Luang Prabang” in Ban Huay Luek Community, Wiang Kaen District, Chiang Rai Province Thailand.

2. To study the identity and persistence of Laotian Diaspora via Khap Thum Luang Prabang in Ban Huay Luek Community Wiang Kaen District Chiang RaiThailand.

\section{Methodology}

Methods of study and research on the subject "Identity of Laos Luang Prabang and Laotian Diaspora in Chiang Rai Province via Khap Thum Luang Prabang”, to study identity establish identity and persistence of Laos Luang Prabang and Laotian Diaspora via Khap Thum Luang Prabang in Chiang Rai Province. This will use the historical approach and use educational guidelines phenomenological research, which is an empirical phenomenon, using data obtained from researching primary sources and secondary sources, and information from oral history and fieldwork, such as participating in activities, in addition to the use of some sociological and anthropology frameworks to engage in data analysis and phenomena.

Also, the study and survey of research-related tasks to analyze the concepts and theories of academics used in the study of identity creation will be seen as the highlight and disadvantage of the theory to be used as a framework for the research of the researchers themselves. As for the presentation of the thesis, it will be presented in the form of an analytical description, a presentation that will help to see every detail.

The ground used in this study is the researchers selected the Ban Huay Luek community, Wiang Kaen District, to analyze the social and cultural characteristics that preserve the identity of Laos, and to study the identity of Khap Thum music that still plays in Ban Huay Luek today. However, Khap Thum Luang Prabang and Khap Thum Ban Huay Luek are considered valuable local cultural heritage. Therefore proposed conservation guidelines develop and inherit to continue to exist, using interviews with leaders and the Laotian diaspora in the village. But for the certainty 


\section{International Journal of Social Science and Economic Research}

ISSN: $2455-8834$

Volume:06, Issue:02 "February 2021"

and clarity of the evidence, the researcher will examine interviews with Laotian diaspora in other villages too, to obtain any inaccurate information. In addition to the interview, researchers will study actively and participate in various rituals and traditions. In the area of the village of the Laotian diaspora people in Chiang Rai widely, to give an overview of how the Laotian diaspora people form a common identity.

\section{Results}

Explaining the identity of the Laotian diaspora people, an important issue that must be addressed and indispensable is the identity of the Laotian diaspora people who are coordinated under the conditions of the area context, it is a different part of the Laos community that is different from other groups in the area (Prasit Leepreecha, 2004). The phenomenon of the relationship between ethnic groups and the state, in terms of social and cultural relations, the Laotian diaspora people interact with their surrounding contexts, to identify the Laotian diaspora people in the community area, with their own existing culture. This is defined by the Laos people of Luang Prabang who have language, traditions, cultures, religions, and beliefs that are unique to Luang Prabang. It is a collective identity of the group, proud and presented to Laos ethnicity through culture, tradition, as well as music arts such as Khap Thum Luang that the Laotian diaspora people show up on local occasions. The definition is the identity of the people's diaspora, so it's not a standstill practice. But choosing certain cultural features to describe the identity of the Laotian diaspora means self-determination. For example, the traditions offered by the villagers under the sense of Laos and the shared feeling of being displaced. As a result, people in the home community are still yearning for and reminding them that they are Laos's people, this causes the process of adapting some of their identities to the context of the space. This reflects that identity is actually fluid and can change over time (Apinya Fuengfoosakul, 2018), and try to resurrect some of the identities to make a difference to people in their ethnic neighborhoods, they also have important functions of the community.

The collective feeling of the Laotian Diaspora is due to the nature of the community's integration in the matter of Laos's people as well. For example, from a group interview in Ban Huay Luek, it is found that the appearance of the arrival of Laos's people will come in ripples; it started with a group of the main families of the village. Over time, the village swelled and the Laos people started crossing to work in various areas of Chiang Rai. And finally, settle at Huay Luek House, or even the Laos people intend to cross from the Laos People's Democratic Republic to live in Ban Huay Luek community (Interview: 2018). In this regard, the identity of Laos people has become one of the tools that are responsible for integrating Laos's people from different areas of Chiang Rai, and some in the Laos People's Democratic Republic who decided to immigrate to Thailand chose to target Ban Huay Luek community like the cultural network, but still connected with the relatives who chose the Laos side as well. In addition to the traditions that have been 
cited above, there is also a particular theme of the dress code to attend the festival as merit. Another characteristic that is observed differently to ethnicity is the appearance of a shoulder cloth, topcoats, and patterns of woven fabrics. Although there are no weavers in the village today, most of them will skip buying fabric from the Laos People's Democratic Republic, because the beautiful pattern is also significantly cheaper on the Thai side. (Interview: 2018)

Nowadays, Thailand has focused more on diverse groups; there are studies on coexistence in diversity. As a result, ethnic groups have been studying ethnicity and successions, to the adoption of identity in the bargain, the ownership of the area, adoption of identity in trade ethnic groups are adapted, more claims have been made, the culture of ethnic groups, too. In this regard, the culture is a medium for conveying the identity of a nation, being used as a tool to express the identity of the people. For example, the Laotian diaspora ethnic group in Huay Luek village, which uses Khap Thum Luang Prabang music to express itself, said that he was a Laos who immigrated from Luang Prabang province into Thailand and lived in Thailand as part of Thailand, and it is Thai people of Laos descent who still yearn for the past and the birthplace they have left. Being amid diversity allows ethnic groups to learn to be part of the area in which they live, showing power and opposition, without losing the culture they belong to, and the introduction of music as a means of conveying Laos identity reflecting through the music in various aspects.

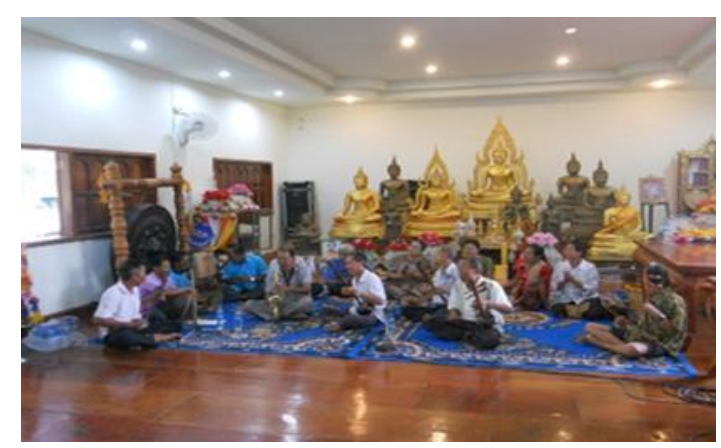

Figure 1: Khap Thum Luang Prabang performance at Ban Pak Ing

Source: Sapanna Kaewtapee (4 March 2013)

By Khap Thum Luang Prabang music in Chiang Rai province, this is a province bordering Laos. There is a ridge of the Mekong River, a borderline from the French period. Which the right bank of the Mekong River belongs to the Laos People's Democratic Republic and the left bank is of Thailand. In the past, there has been no occupation of the so-called national state. The people can come to each other freely between Thailand and Laos; it is like a brotherhood with roots that 
International Journal of Social Science and Economic Research

ISSN: 2455-8834

Volume:06, Issue:02 "February 2021"

come from the same source because there are similarities in the spoken language, dress, culture, and tradition, as well as arts and culture in various fields. For example, the interactive singing between the female and the man of the central Thai people is called "Lam-Dtàt", we can also find the characteristics of the singing, the lovemaking, and start with the word "Lam" meaning "Singing", and it can be found in central Thailand. This type of vocals can be found in northern Thailand, but it is called "Khap". However, the words "Lam" and "Khap" are in the Laos People's Democratic Republic, it is a claim of folk and local music. For example, "Lam" is a calling for singing in the southern part of the Laos People's Democratic Republic, and such as "Lam Si Phan Don" and "Khap" called the northern part of the Laos People's Democratic Republic, such as "Khap Sam Nuea" because he was born in Ban Sam Nuea, Hua Phan District, etc.

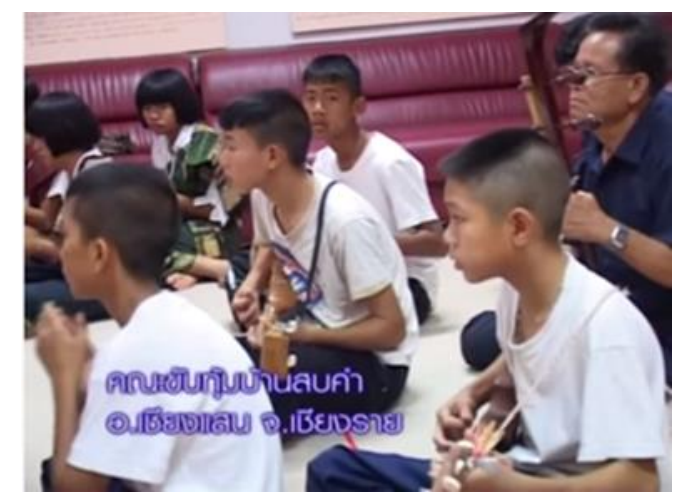

Figure 2: Khap Thum Luang Prabang performance at Ban Sop Kham

Source: Pan Sang Rung (2013)

The Laos ethnic group is another group affected by colonialism, the state's territory is represented by the first and new arrivals, and the evacuation of the area is a factor in the struggle for survival. The phenomenon of the movement of Lao people who came to Chiang Rai in Thailand represents the connection of the culture and way of life of the people in the area, especially the Laos ethnic group at Ban Huay Luek community, when immigrants crossed into Thailand, they were evacuated, their traditional culture has been introduced in Thailand. For example, Khap Thum music is a folk song of the Laos ethnic group that reflects the unique Laos identity of The Village of Huay Luek Laotian diaspora in Thailand.

According to the statement, "Khap" is a vocal dialogue between men and women, in a teasing manner aside, in Laos People's Democratic Republic, Khap has many names, such as "Khap Sam Nuea", it is a sung to tease. In Mueang Sam Nuea, Hua Phan District, in the Laos People's 
International Journal of Social Science and Economic Research

ISSN: 2455-8834

Volume:06, Issue:02 "February 2021"

Democratic Republic "Khap Xieng Khwang" located in Xieng Khwang, east of the Laos People's Democratic Republic, and "Khap Thum Luang Prabang" located in Luang Prabang which is the old capital of the Laos People's Democratic Republic. However, this Khap Thum Luang Prabang is an old song, a classic song of Luang Prabang, because this melody has been adapted into many Thai songs, for example, a song called "Sawan Bannok", which belongs to the "Hope Band", or bring a melody to Thai meat, such as the song "Lam Klom Thung", which the author said in the book "Behind the Famous Music", which is said to be titled "Lam Khap Thum", it's a song with a melody of Luang Prabang that is melodic and easy to listen to, there are mixed dance melodies, it was adapted to be modern and included in the semi-final lyrics, and from studying the cultural context of the Mekong Basin, In 2015, it was found that Nam Pat District, Uttaradit Province, was an area of Laos people who migrated from northern Laos near Luang Prabang, in the old days, there was a song like this. However, there are no singers today, and the characteristics of this song are explained that when they finish the song, there will be people who say "ao kâo bpai" and "yer kâo bpai", some "ao táe lá wáa". Besides, exploring and studying areas with ethnic Laos's people, the group is also a group of ethnic Laos's people. There are also ethnic Laos's people who have migrated to Chiang Rai. It is distributed in districts such as Si Don Chai, Chiang Saen District, Chiang Khong District, and Wiang Kaen district, etc. There are many expressions of music culture, as well as musical instruments used in Chiang Rai mainly as string instruments such as soprano fiddle (sor êe), alto fiddle (sor ôh), rhythmic instruments include single-sided drums, small cymbals, and cymbals.

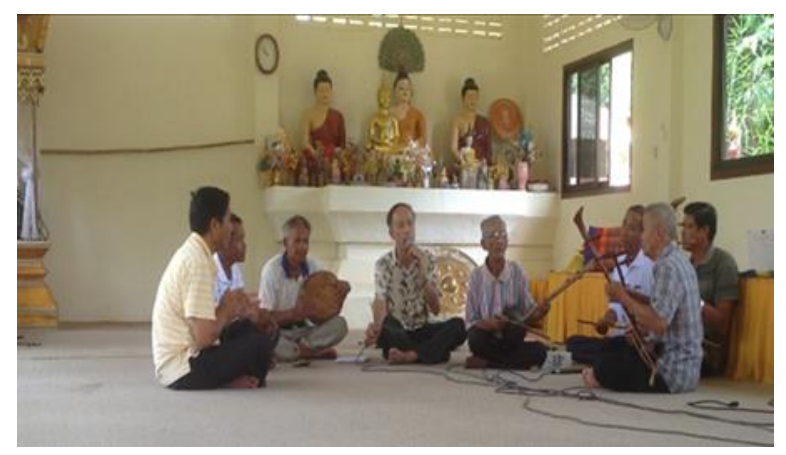

Figure 3: Khap Thum Luang Prabang performance at Ban Huay Luek

Source: Sapanna Kaewtapee (25 May 2015)

According to a study of Khap Thum Luang Prabang music in Chiang Rai province from 2015 to the present day, there are three groups of Laos ethnic groups that used Khap Thum Luang Prabang, that is; Group 1, Ban Sop Kham Community, Chiang Saen District, is to be passed on to interested youths to perform within Phra That Pha Ngao Day, to show tribal culture to visitors 


\section{International Journal of Social Science and Economic Research}

ISSN: 2455-8834

Volume:06, Issue:02 "February 2021"

to the temple only, it was originally used by a group of elderly people to play. With Mr.Khao Sukpheng and Mr.Suk Sukpheng were the band's coordinators at the time, Khap Thum Luang Prabang's band, Ban Sop Kham, is a string instrument and banjo. Later, when Mr.Khao Sukpheng was unable to play music, he was able to play the song. As a result, the band gradually reduced its role to the Wat Phra That Pha Ngao. But interestingly, there are players of a wide range of ages, ranging from old, middle-aged, and fun-loving, to performers and rehearsals, the abbot of Wat Phra That Pha Ngao is a supporter. Group 2, Ban Pak Ing community group, where Mr.Phai Boonchuay is the band's leader and gathers the villagers to play music, and in visiting the area again in 2017, it was found that the Ban Pak Ing local Laos music band no longer exists. Since Mr.Phai Boonchuay died, there are no successors and no mainstays to gather people to play (Interview: 2018). If analyzed by the local authority, the Ban Pak Ing band is much more complete and complete than Ban Sop Kham and Ban Huay Luek, but it is not able to maintain the music. Group 3, Ban Huay Luek Folk Band, currently the only group that can sustain and maintain Laos Luang Prabang identity in the most cohesive music, it is a group of Laos people Ban Huay Luek, Wiang Kaen District, Chiang Rai Province. Because it is a group that still has Laos's identity, both in terms of culture, tradition, dress and the music performance of Khap Thum Luang Prabang.

From the study of Ban Huay Luek community, Wiang Kaen district, Chiang Rai province, to analyze the social and cultural characteristics that maintain the identity of Laos and to study the identity of Khap Thum, which is still playing in Ban Huay Luek today. Khap Thum's song Ban Huay Luek community, Wiang Kaen district, Chiang Rai province with Khap Thum Luang Prabang music that still appears in Laos today, still details the identity of khap thum songs that are identical and different through musical instruments, melody, and lyrics. However, the lyrics of Khap Thum Luang Prabang and Khap Thum music at Ban Huay Luek, Wiang Kaen district, Chiang Rai province. It is considered to be a highly valuable local cultural heritage. The findings from this research suggest a way of conservation, development, and succession to survive.

The area is known to other ethnic groups as Ban Huay Luek, Wiang Kaen district, Chiang Rai province. For example, people in Chiang Rai and ethnic groups in Laos. Also, under the arrival of immigrants who have to settle in Thailand. When considering the cultural context of the area, many cultures are similar to the culture of the Lao people, and some of the same are the original culture of the area. It has a long-standing relationship with the way of life. However, ban Huay Luek has a distinctive spot that can be distinctly divided from the neighboring communities. The first is the use of the language in which the villagers still speak Laos as the main language of the village, and the Laos alphabet (there are few), and the choice to maintain the Laos cultural way of life. It's a motherland that comes from, especially the festival, the merit, and when you have lived in Thailand for a long time, the process of reviving some of the cultures and identities that 


\section{International Journal of Social Science and Economic Research}

ISSN: 2455-8834

Volume:06, Issue:02 "February 2021"

were originally practiced while in Laos, help to remember who you are at all times, the atmosphere of interaction in the village and the Laos people together feels united. And it is also an important factor in attracting Laos's immigrants, some of whom decided to settle in Ban Huay Luek, Wiang Kaen district, Chiang Rai province. Nowadays, there are festivals, cultures, and traditions in the village that reflect the identity of Laos throughout the year.

The traditions of Huay Luek villagers, Wiang Kaen district, Chiang Rai province, present under the conscience of Laos and a shared sense of being displaced. As a result, people in the Ban Huay Luek community continue to yearn and remind themselves that they are Laos's people and make the process of adapting some of their identities to the context of the area. This reflects that the identity is fluid and can change at all times (Apinya Fuengfoosakul, 2018) and try to resurrect some of the identities, to make a difference to people in the vicinity of their ethnicity, and those identities are also important functions of the Ban Huay Luek community, this is due to the nature of the community's integration in the same way as the Laos people. In interviews with villagers in Ban Huay Luek community, Wiang Kaen district, Chiang Rai province, it was found that the nature of the arrival of Laos people came in several times, starting with the main family groups of the village. Over time, the village swelled and the Laos people started crossing to work in various areas of Chiang Rai. Finally, settle at Ban Huay Luek, or even the Laos people intend to cross from Laos to live at Baan Huay Luek, Wiang Kaen district, Chiang Rai province (Interview: Pornsawan Buntan, 6 October 2018). In this regard, the identity of Laos's people has become one of the tools that are responsible for the integration of Laos people from different areas of Chiang Rai and some parts of Laos who decided to emigrate to Thailand. Like the cultural network, there is still a connection with the relatives who choose to live on the Laos side.

"Khap Thum Luang Prabang" of Huay Luek villagers, Wiang Kaen district, Chiang Rai province. It is a non-material culture of Laos's diaspora and includes Laos's people in Luang Prabang province in Laos. In Khap Thum, it is often driven by reading a book (like reading the word of the Lanna people). In addition to The Khap Thum of Laos Luang Prabang, Laos's diaspora people in Huay Luek villagers, Wiang Kaen district, Chiang Rai province, there are also other Luang Prabang folk songs such as Salang song, Samshao song, Songkon Lodkhai song, Mayong song, Naksadung song, and Dok Din song. These songs are currently being released at Ban Phon Phaeng and Ban Chiang Man, Luang Prabang province. In various merit-making festivals such as housewarming, by si sukwan, boon phawet, weddings, cloth merit favors, and other merit favors. From studies and interviews with a musicians press release on culture and tourism in Luang Prabang province (10 July 2019), Khap Thum was found to be an interactive singing between men and women, a folk song of Luang Prabang province, a culture that is not an object developed from reading, according to teachers and senior scholars, it said there was 


\section{International Journal of Social Science and Economic Research}

ISSN: $2455-8834$

Volume:06, Issue:02 "February 2021"

currently no research or storage agency, clear historical evidence only the book (document) of "Than-HuamPhan RattanaWang" (Luang Prabang Books, 1998). It has been recorded in part, but it does not provide detailed information that mentions the texture in the history of the origin of the data but is only consistent or predictable. It does not specify who the author is and who wrote the note, and there is no endorsement, which only writes and writes poems. Laos's diaspora in Huay Luek villagers Wiang Kaen district Chiang Rai province, there is still the succession of Khap Thum Luang Prabang, and the chorus still preserves the most original Khap Thum in Luang Prabang province. According to the evidence of Khap Thum's unique performance of Luang Prabang's Laos people, the Lan Chang Kingdom. In ancient times, there were celebrations of local music, with "Khap Lam" in the palace of Laos people, in the old days, Khap Thum responded with a real spirit. According to the elders, the newlyweds that Khab answered often were husband and wife. If the newlyweds would talk (lom gan), the opportunity to see each other, the time is merit. Most of the villagers from all over the north and south will meet, and there's a chance to sing (khap tong gan). The answer is often to be loved, and to be a wife, and with the strict "heet sip-song-kong-sip-see" tradition. If a woman has a child before marriage, it is considered a bad person. It is necessary to pay a penalty for the police (bpap-mai) to pay for the penalty, which is to use a pig to do a ghost house. Therefore, parents treat their children well. If you love each other, you have to ask your parents to be wives. This is the best culture that has been engaged in the expression of the native Khap voice of Luang Prabang for generations. No matter what work is required, Khap Thum and the reading of the book are answered with pleasure from the newlyweds, and the indigenous Khap voice is born locally, Laos diaspora in Ban Huay Luek, Wiang Kaen district, Chiang Rai province, is also followed.

A group of folk bands in Ban Huay Luek, Wiang Kaen district, Chiang Rai province. Today, only one group can maintain and maintain the most cohesive Laos Luang Prabang identity in music, because it is a group that still has Laos's identity, in terms of culture, traditions, dress, and music, Khap Thum in Luang Prabang. Which the Khap Thum in Luang Prabang band of Ban Huai Luek, Wiang Kaen district, Chiang Rai province, has been established and played continuously, and there are leaders of 2 generations: The first edition was established around 1977-1987 by Mr.Puy Pongsawat (now deceased) there are only 4-5 players in this version. The musical instruments played are Seo Oh, Seo Yi, Seo Lai, Cymbal, and Cymbals. The second generation runs from 1987 to 2011, the second generation is considered the most prosperous version because Khap Thum became known as the folk music of the Laos ethnic group in Chiang Rai Province, and there is a Thai PBS television station "pan-saeng-rung", to film the Laos ethnic folk culture singing Khap Thum Luang Prabang on November 29, 2009. 


\section{International Journal of Social Science and Economic Research}

ISSN: $2455-8834$

Volume:06, Issue:02 "February 2021"

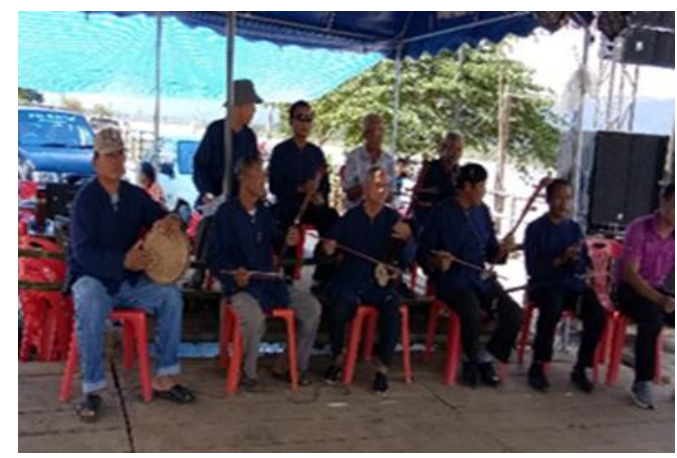

Figure 4: Khap Thum Luang Prabang Band, Ban Huay Luek

Source: Sapanna Kaewtapee (4 March 2013)

"Khap Thum Luang Prabang", in Ban Huay Luek, Wiang Kaen district, Chiang Rai province, the researchers removed the note from a video recorded from the play and sung in the field, Khap Thum Luang Prabang melody was found in the Laos diaspora in Huay Luek villagers, Wiang Kaen district, Chiang Rai province, a total of 5 main sounds are used. This includes Do (C), Re (D), Mi (E), Fa (F), Sol (G), and La (A). Therefore, when using Thai music theory to explain this phenomenon, it can be analyzed that the melody Khap Thum Luang Prabang of Laos diaspora people in Ban Huay Luek, use the "pentatonic scale" staircase or have a total of 5 main sound groups. The soundtrack from the song is "Do-Re-Fa-Sol-La" when it's arranged; the "Fa-Sol-LaRe-Do" sound group is in the "Fa" staircase. As for the length of Khap Thum Luang Prabang melody of the Laos diaspora in the villager's Ban Huay Luek community is unstable and the petition will stick to the melody and rhythm. The rhythm used in Khap Thum of Ban Huay Luek is small cymbals, cymbals, and drums. And for my part, Khap Thum Luang Prabang of Ban Huay Luek, there will be a complete difference to Luang Prabang Khap Thum. As well as singing, the villagers have a smaller and less erratic number of words, depending on the idiom that the petitioner can think of at the time, but you'll have to sing to the rhythm of the music and still use the original melody of Luang Prabang, the language is used in some of the same ways and applies Thai.

In terms of rhythm, used in melody, it is found that there is an unstable and unstable rhythm, but the rhythmic pattern is in the structure of the melody, don't make too many adjustments, the rhythm here does not mention the melody of the drum. It controls the band's slowness and is used to measure music sentences, but the rhythm of the drums cannot be studied in depth in a short time. It is important to mention the overlapping rate that is used in the characteristics of Khap Thum Luang Prabang. It concludes in a specific part of the rhythmic pattern used in the melody that it flows and changes according to the musician's perspective but is limited to the 


\section{International Journal of Social Science and Economic Research}

ISSN: $2455-8834$

Volume:06, Issue:02 "February 2021"

scope of the melody, and the rhythm is similar to the rhythm used in Khap Thum Luang Prabang in Laos.

As for the content of the song Khap Thum Luang Prabang is a folk song with interactive lyrics among the young. The newlyweds who answered often got married, lyrics, and melodies in the drive of Ban Huay Luek, Wiang Kaen district, Chiang Rai province. Therefore, it is different from the original Luang Prabang. It is seen by the social and power relations dimensions that displaced Laos's people choose to express their ethnic identity in a new context. The environment in the society, the people of the city, and the nearby cultures is a social operation or a process that determines the position of the identity of Laos's diaspora and adheres to the group and awareness of the Laos Luang Prabang people. For example, the petition is a kind of teasing, the men would compare themselves to saying that; "I'm a poor man Where women don't care going to flirt with someone, I don't know if they have a partner or not and likened to a noble, beautiful woman, browed eyebrows, red lips, if not a younger sister as a spouse I want only one of you", it can also be seen that The Khap Thum Luang Prabang of Ban Huay Luek Khap Thum melody has been used economically, "invite diners to eat fish" Ban Huay Luek is abundant because of the Mekong flowing through it, there is a natural beauty, "Kaeng Pha Dai". Even though Khap Thum's Ban Huay Luek it's not an interactive drive, because it's the only male driver, but the content remains the subject of teasing and inviting them to visit their homes.

And from the lyrics of Mae Khap Ban Huay Luek, Wiang Kaen district, Chiang Rai province, it was found that the song would be like "sneaking in like a lover, but not because he had a wife, but waiting for him to look, moan, wait until he was dry, men didn't look, walk until the bag was broken, walk edging in difficulty, had to go to the water bag to find the beloved man". Although the women in the village can still sing Khap Thum, they are often not popular with the band, for several reasons: Khap Thum music is not just about Khap for fun in the village. But Khap is the expression of the village identity. Therefore afraid that the tone of voice will not be good and another is Afraid that there will be family problems because if you have to go to perform, you will have to go home late Will not have much time at home.

So, what are you doing here? How to inherit and how to conserve Khap Thum Luang Prabang of Laos diaspora people in Ban Huay Luek, Wiang Kaen district, Chiang Rai province, it is considered that there is a process in which the villagers can maintain their Laos identity, Khap Thum Luang Prabang is a medium that connects and reflects the relationship between Thailand and Laos. But there is a similarity or difference to the duration and space of Khap Thum Luang Prabang music in Luang Prabang, for this reason, both in the lyrics of the musical instrument of Laos's diaspora. Therefore, it is different from Laos in Luang Prabang. However, the identity of the Laos diaspora remains and is inherited through the method of conserving Khap Thum Luang 
International Journal of Social Science and Economic Research

ISSN: 2455-8834

Volume:06, Issue:02 "February 2021"

Prabang in the context of the cultural and social area of the People of Laos diaspora in Ban Huay Luek, Wiang Kaen district, Chiang Rai province.

\section{Discussion}

Ethnic identity identification in Khap Thum Luang Prabang of Ban Huay Luek Community, Wiang Kaen District, Chiang Rai Province, has been modified, the combination and fluidity of the time, such as the use of musical instruments to play Khap Thum in Chiang Rai province. It is found that a group of Laos's people who had been living in various areas, such as the Laos Ban Sop Kham group, the banjo player, and the tom drum join Khap Thum. In the village of Pak Ing with the dulcimer and the saxophone, entering the Khap operator, for the Laos people of Ban Huay Luek, there is no xylophone as the main instrument, they will use fiddle and drums as well as play gongs for Khap. This is different from Luang Prabang's Khap Thum played in government and royal courts; there will be both "Nang Nad Ek" and "Nang Nad Tho", gongs and various percussion instruments. For Ban Pak Ing and Ban Sop Kham, while surveying Ban Pak Ing, there is still a band style that combines international instruments with the instrument. As for Ban Sop Kham, apart from only meeting people who sing we can also find teaching Khap Thum inside Wat Phra That Pha Ngao. There is still only Ban Huay Luek, which still has traditional singing and chorus. For example, there are no other instruments Join the play there is still only each type of fiddle, and the percussion instruments are drums, small cymbals, and cymbals.

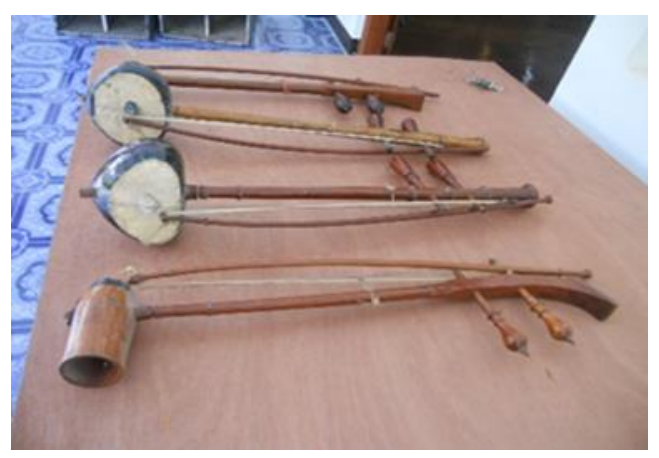

Figure 5: Musical instruments for performing Khap Thum Luang Prabang performance

Source: Sapanna Kaewtapee (25 May 2015)

The use of Laos's instruments in Chiang Rai, especially Laotian diaspora, Ban Huay Luek, is a musical instrument made from natural materials and derived from relatives on the Laos side. The repair material, such as the fiddle line, uses bicycle brake cables, which are locally available materials. The skull in the fiddle is made of hardwood, pierced to the hollow inside, and 


\section{International Journal of Social Science and Economic Research}

ISSN: $2455-8834$

Volume:06, Issue:02 "February 2021"

stretched with animal skin on one side. Another type of fiddle, the skull is made of coconut shell, on one side pierced and stretched with animal skin. It can be seen that percussion instruments that are the main instruments of music in the Laos royal court not available in the Laotian diaspora group. Because of the immigration that the group came only and brought the culture with them, cannot bring musical instruments. The instrument used is an instrument that is in memory, when immigrants come to see Thailand music culture that is already similar to their own, it can be used as a prototype and used together.

The instrument can therefore be divided into 2 parts: The first part is produced by imagination or experience seen. The second part is obtained from relatives on the Laos side or receiving budget support from government agencies and Khap Thum Luang Prabang supporters, etc.

One of the most notable aspects of the ethnic identity of Luang Prabang, there are constantly changing, blending, and fluid, such as singing Khap Thum, and the Laos Ban Sop Kham has brought the banjo player to play Khap Thum. The Laos people of Ban Huay Luek have no xylophone, which is the main master machine of Laos bands, using fiddles, drums, beating gongs. This is different from Luang Prabang's Khap Thum played in government and royal courts; there are both xylophone and alto xylophone. The playing of Khap Thum in various traditions at Ban Sop Kham no longer exists, only teaching in the temple and Ban Pak Ing is no more Khap Thum at present, as well as Ban Huay Luek, still playing in important traditions and playing in daily life when socializing. However, the lyrics and melodies are different from Luang Prabang manuscripts. It can be seen that the dimensions of social relations and the power relations chosen by the Laotian Diaspora that exhibit ethnic identity in new contexts in neighboring urban and intercultural societies. This is a social operation or a process to determine the location of the identity of the Laotian diaspora, and it's a group and a sense of the Laos Luang Prabang of Ban Huay Luek.

The music played Found that popular songs expelled after reading Laos books in Luang Prabang are Khap Thum song, Salang song, Samshao song, Songkon Lodkhai song, Mayong song, Naksadung song, and Dok Din song. Wich would prefer Khap Salam song and Samshao song before the first song, if there is time left or work that goes, it is a big welcome to Khap Thum (interview: 2019), and the rhythm used in the music is the most instrumental style of the song. It can be smooth in the melody and technique of the instrument, but for Laos, Ban Huay Luek will only know some songs such as Khap Thum song, Salang song, Samshao song (Interview: 2019), and will be popular with Khap Thum after reading the book. At present, it was found that Khap Thum was left with only one melody that was Khap Thum song, and the group that cans still Khap is a group of people aged 30 years and over. The younger group found that they knew Khap Thum song because they heard the adults sing, and the broadcasting tower in the house 


\section{International Journal of Social Science and Economic Research}

ISSN: $2455-8834$

Volume:06, Issue:02 "February 2021"

plays some music, etc. As for the Salang song and Samshao song, the only ones Khap got were Mr. Peng Srisawat and Mr. Pan Kanyadet.

The succession of Khap Thum Luang Prabang is a memorization succession called "múk-kàbpaa-tà", which Chaimongkol Trakuldee (1999) has described as "Telltale literature" as a literature that is not written in writing but in people's memories. The successors need memory and patience to practice until they become skillful. In addition to having a witty reaction to interact with one another promptly and having good knowledge around them, you can find the rhymes to match the melody. At the same time, studies of Laos Luang Prabang and Laotian diaspora identities in Chiang Rai through Khap Thum Luang Prabang have also been found to be characteristic of one-toward-many cultural heritage. The Khap Thum band was inherited for three generations when the band's first-generation leader died, the band's second-generation leader was appointed to inherit the band, until the third generation, which came from the reunion with the chief as a gathering member of the band, but was troubled by the band members having to pursue a career to raise a family. The Khap Thum Luang Prabang of Laotian diaspora is a fun and relaxing play, and it's a shared memory of the displaced people who still yearn for the past, once living on the land of the motherland in Luang Prabang, Khap Thum is a fun activity for the displaced.

If there is no succession and conservation, the day will collapse, so it is good that the people of Laos diaspora in Ban Huay Luek, Wiang Kaen district, Chiang Rai province, Khap Thum Luang Prabang is cultural preservation and cultural heritage show, and Khap Thum Luang Prabang is also used, to express the identity of Laos people to the public in the diversity of the culture of Wiang Kaen district.

"Khap Thum Luang Prabang" in various traditions both merit-making and social gathering according to various occasions, such as merit-making, boat races, and Buddhist lent, there will be both Thai and Laos cheering for fun around Khap Thum. Villagers Ban Huay Luek, Wiang Kaen district, Chiang Rai province, also have a typical Khap Thum. For example, relaxation, with its characteristics: the use of gentle melodic language and Khap Thum, which is a tease between women and men, the lyrics are thought to be fresh, interactive with the witty reaction of Khap Thum. This, Khap Thum Ban Huay Luek, Wiang Kaen district, Chiang Rai province, is directly influenced by Luang Prabang, but there is a difference that the instrument is played, Khap Thum Ban Huay Luek does not have a xylophone.

From Laos Luang Prabang to Laos Ban Huay Luek, Wiang Kaen district, Chiang Rai province, can be seen as the ethnic identity of Lao Luang Prabang of Lao people Ban Huay Luek continues to exist and exist to this day. In this regard, Ban Huay Luek ethnic identity formation process correlates with the historical, ethnic, social, and cultural dimensions of Luang Prabang through 


\section{International Journal of Social Science and Economic Research}

ISSN: $2455-8834$

Volume:06, Issue:02 "February 2021"

rituals, traditions, and music activities. Having a social space to express or choose to bring up a musical identity like Khap Thum Luang Prabang is a hallmark of the community, creating a system of value of identity at an individual and group level. Also, Khap Thum is a sensational welder of Laos Luang Prabang. The process of establishing an identity as a Laos's diaspora that needs to be dispersed relocates and feel unfamiliar with the territory that goes to the new place, still want to go back to their motherland because they also share language and culture (William Safran, 1999). The desire to return to the motherland of the diaspora is different from the immigrant. Such definitions displaced people may not always want to return to their motherland. For example, black people in Europe America, and Africa do not want to be separated from the rule of the country in which they live. They want to live in those territories, still with the culture of the people themselves (Apinya Fuengfoosakul, 2018). Like the Lao people Ban Huay Luek, Wiang Kaen district, Chiang Rai province, where some people may not even want to return to their motherland, but the relocation to their destination country, however, has not been maintained. The ethnic identity and culture of Lao Luang Prabang clashed; it is a blend of the destination culture of other ethnic groups in the village.

In addition to the Laos people who have maintained their Laos identity to preserve the public sphere for their ethnic groups, the group has also maintained its identity. Another important factor that can be maintained is that Laos's people living on the other side of the Mekong River, both Laos's people are always coming to each other. Especially when there are merit events or festivals such as boat races, where villagers in Laos will cross to join the Laos people in Ban Huay Luek, Wiang Kaen district, Chiang Rai province. This kind of context is the shifting of people of the same ethnicity or crossing the border of people without meaning. What is the medium of this shift is the same ethnic feeling that, even if they do not coexist in the same area in the modern state definition, they will not be able to live together. Is to live in the same state area, but the common ethnic realization is a bond of the identity of "Laos Luang Prabang" (Yos Santasombat, 2008). In addition to the activities, the Lao ethnic group in Ban Huay Luek, Wiang Kaen district, Chiang Rai province, has a sense of nostalgia. This makes it possible to have Laos Luang Prabang ideas with myths, stories, literature, art and culture, and social norms; one of the most notable aspects of ethnic identity in Khap Thum Luang Prabang has been modified, blended, and fluid at all times. For example, Khap Thum singing of Laos Ban Sokham, Chiang Saen District, Chiang Rai province will be modified and blended, the banjo player is a driving player. This is different from Ban Huay Luek, Wiang Kaen district, Chiang Rai province, where there is no xylophone, the operator Khap Thum. It is considered the main instrument of the Laos music band but uses the fiddle, drum, and gong to play instead. Which, it is different to playing Khap Thum Luang Prabang, who plays in the bureaucracy and royal duties, is both alto bamboo xylophone and alto xylophone. However, playing Khap Thum in some traditions in Chiang Rai province is no longer available, but only teaching in temples, such as at Ban Pak Ying, Chiang 


\section{International Journal of Social Science and Economic Research}

ISSN: $2455-8834$

Volume:06, Issue:02 "February 2021"

Khong district, Chiang Rai province, is not Khap Thum. In Ban Huai Luek, Wiang Kaen district, Chiang Rai province, it continues to play in important traditions and play in the life of the day when socializing. Unlike the original Luang Prabang, it is evident that the social and power relationships that Laos's diaspora chooses to express ethnic identity, amid the new contexts surrounding the society of the people and cultures nearby. It's a social operation or there is a process to determine the position of the identity of The Laos diaspora and its divisions and the yearning for the Laos Luang Prabang of Ban Huay Luek, Wiang Kaen district, Chiang Rai province as well.

Over the years, Laos's diaspora ethnic group Ban Huay Luek, Wiang Kaen district, Chiang Rai province recognized by the state, it is observed by obtaining Thai nationality, which is a sign that certifies Thai ness. In the past, Laos's ethnic groups have been watched by the Thai government. Because of the period of migration in the cold war era, looking at people from countries that use communist-socialist regimes as a threat to state security. So it's not that strange, but after the end of the cold war, the Thai government does not have a view to the communist country on security issues, which may be diminished due to the state's key issues is an economic perspective. As a result, the Thai government's views on Laos's diaspora have changed; the state has turned to Laos's diaspora to become a boon for the state, especially when cultural tourism has become popular, Laos diaspora group becomes a cultural capital that will enter the process of becoming a commodity, commodification (Chiang Rai, 2016). The Thai government has given Laos's diaspora "Khap Thum Luang Prabang" identity area to perform at ceremonies or important days in villages, districts, or Chiang Rai provinces that have supported this show. For example, the events of Wiang Kaen district, the department of sub-district administration, or even the Chiang Rai provincial event, invited the Laos diaspora group to perform, so Khap Thum Luang Prabang of Ban Huay Luek, Wiang Kaen district, Chiang Rai province is one of the activities that have been elevated to perform on the provincial stage. The group of villagers also performs Khap Thum Luang Prabang almost every time the traditional activities, such as during the Buddhist lent festival. But in Khap Thum Luang Prabang at Ban Huay Luek, Wiang Kaen district, Chiang Rai province, there is no one playing the same xylophone as Luang Prabang. The difference between Khap Thum Luang Prabang and Ban Huay Luek, Wiang Kaen district, Chiang Rai province (Phansangrung, 2015) and also see the adaptation of Laos's diaspora, in the area as well.

\section{Conclusions and Suggestion}

Nowadays, Thailand has focused more on diverse people and studied coexistence in diversity. As a result, ethnic groups have been studying the existence of ethnicity. Succession, to the adoption of identities in bargains, representing ownership of the area, adoption of identity in trade ethnic groups are adapted, more claims have been made, the culture of ethnic groups, too. Because 


\section{International Journal of Social Science and Economic Research}

ISSN: 2455-8834

Volume:06, Issue:02 "February 2021"

culture is a medium for conveying the identity of a nation, it is used as a tool to express the identity of the people. For example, the ethnic group of Laotian diaspora, which uses Khap Thum Luang Prabang to express him, said that he was a Laos who immigrated from Luang Prabang province into Thailand and lived in Thailand as part of Thailand, and there is a feeling that Thai people of Laos descent are also yearning for the past of their homeland. Being amid diversity allows ethnic groups to learn to be part of the area in which they exist, it's a show of power and opposition without losing the culture that comes with it, the music is a reflection of Khap Thum Luang Prabang in various aspects.

The process at the Laotian diaspora in Ban Huay Luek community, Wiang Kaen District, Chiang Rai Province, it is possible to preserve the Laos identity of the Laos people, the song of Khap Thum Luang Prabang. This is a medium that connects and reflects the relationship between Thailand and Laos, as well as the traditions of culture that have continued to follow and have been passed down to the present day. How is it similar or different from the song Khap Thum Luang Prabang in Luang Prabang?, and why is that so in terms of lyrics, melodies, instruments, and how are the Laotian diaspora compositions different or persistent?, or how different and what makes the Laotian diaspora identity? why inherit it?

For "Collective Identity" of the people of Laotian diaspora in Ban Huay Luek Community, Wiang Kaen District, Chiang Rai Province, due to the nature of the community's integration, the focus is on the same Laos people. Although the nature of the visit began with a group of the village's main families, over time the village grew and there were Laos's people who started crossing to work. It is distributed throughout the area of Chiang Rai province and finally settled in Ban Huay Luek community, or even if they intend to cross from the Laos People's Democratic Republic to evacuate to ban Huay Luek community. The issue suggests that the identity of Laos's people has become a tool to be the center of Laos from different areas of Chiang Rai. Some areas in the Laos People's Democratic Republic who choose to live on the Laos side are still connected, and have a kinship relationship, and have always been characterized by cultural networks. Besides, under the arrival of immigrants who have to settle in Thailand, when considering the cultural context of the area, it is found that some things are similar to those of Laos. Some of the same is the same culture of the area, which has long had a long-standing relationship with the way of life but has a distinctly divided point from the neighboring community. The first is the use of the language in which the villagers still speak Laos as the main language of the village, Laos characters are used (there are few) and choose to maintain the Laos cultural way of life, which is the motherland that comes from, especially in the festival, merit work and having lived in Thailand for a long time, the process of reviving certain cultures and identities that were originally practiced while in Laos helps to remind yourself of their identity at all times. The atmosphere of interaction in the village and the Laos people together 


\section{International Journal of Social Science and Economic Research}

ISSN: $2455-8834$

Volume:06, Issue:02 "February 2021"

feels united $\mathrm{t}$ is also an important factor in attracting some new migrants to settle on the Thai side. Nowadays, it is found that there is a festival in the village, the village culture, and traditions that reflect the identity of Laos throughout the year, reflected by interviews and observations from Laotian diaspora.

Therefore, the Khap Thum Luang Prabang song is used in different contexts of the Laotian diaspora in Ban Huay Luek community. The song Khap Thum Luang Prabang is used in various events, in addition to the general merit of the village, because Khap Thum Luang Prabang is more than just a song made for driving, for fun, or just for teasing. This, Khap Thum Luang Prabang represents the Laotian Diaspora ethnic group in Chiang Rai Province, because if this ethnic group is mentioned, the first thing everyone will talk about and know about the village of Laotian diaspora people is the Khap Thum Luang Prabang song. Therefore, Khap Thum Luang Prabang is the definition of the word Laotian diaspora, a song that conveys ethnicity beyond the Laos language, and the dress code is indicative of Laos, as well as the traditions that are specific to these Laos ethnic groups. Therefore, Khap Thum Luang Prabang song, in addition to being the identity of the ethnic group it is also a representative in the relations of the brotherhood between Thailand and Laos, which reinforces the fraternity since before the national state was defined.

Explaining the identity of Laos's people ban Huay Luek Important issues to be discussed and indispensable it is a matter of identity of Laos's people in the area of Ban Huay Luek with a collective character that is subject to the conditions of the area context. It is a different part of the Laos community that differs from other groups in the area (Prasit Leepreecha, 2004). The phenomenon of ethnic and state relations and the social and cultural relationships in which the Laos diaspora interacts with the surrounding context, to identify the Laos diaspora in the community area with its own culture. Thus it is defined by the people of Luang Prabang as Laos Luang Prabang with language, tradition, culture, religion, and beliefs that are unique to Laos Luang Prabang as the collective identity of a group that prides itself on ethnic Laos ethnicity through culture and tradition. There is also a musical art such as Khap Thum Luang Prabang, which is the Laos people of Ban Huay Luek, who show up on local occasions. The definition of Laos's diaspora is not a stagnant practice, but choosing certain cultural properties to describe the identity of Laos's diaspora means more self-definition.

If there is no succession and conservation, it will collapse, so it is good for Laos's diaspora Ban Huai Luek, Wiang Kaen district, Chiang Rai province, has been preserved and preserved for the culture of Khap Thum Luang Prabang. In addition to being a cultural preservation show, Khap Thum Luang Prabang is also used to express the identity of the Laos people to the public in the diversity of the culture of Wiang Kaen District. In this research into the field, the information collected at the Khap Thum Luang Prabang of Laos's diaspora in ban huai luek area, Wiang Kaen district, Chiang Rai province. This is a one-way study or one province. The next study may 


\section{International Journal of Social Science and Economic Research}

ISSN: $2455-8834$

Volume:06, Issue:02 "February 2021"

be conducted in other villages and provinces with similar or different cultures, to be able to compare characteristics. As well as the folk music culture of Laos's diaspora in Ban Huay Luek area, Laos's dialects Thai in communication are important and relevant to the lifestyle of the local Laos people. Researchers can use these cultures to study data based on the anthropological method, to save and uphold the local folk wisdom to remain a land pair

\section{References}

Berger, P., and Luckmann, T. 1967. The Social Construction of Reality: A Tredtide in the Sociology of knowledge. New York: Anchor Book.

Charoenphol, K. 2010. Identity Management of Thai Private Universities, Case Study:NorthChiang Mai University. Chiang Mai: Dissertation, Mae Jo University.

Fuengfoosakul, A. 2018.Identity, theory review, and conceptual framework.Bangkok: Office National Research Council.

Jaruvorn, K. 1998. Study of contemporary Thai music and social responsibility identity of Chulalongkorn University students.Master's thesis.Communication Arts (Mass Communication) Chulalongkorn University Graduate School.

Jenkins, R. 1996. Social Identity. London and New York: Routledge.

Lepreecha, L. 2004. Creation and inheritance of the Hmong ethnic group. Social Research Institute: Chiang Mai University.

Phikulsri, C. 2009. Aesthetic identity of Mekong River music.Faculty of Fine and Applied ArtsKhon Kaen University.

Safran, W. 1999.The Displaced and Social Space Creation: A Synthesis of Principles and Theories.Faculty of Humanities and Social Sciences, Khon Kaen University, Thailand.

Santisombat, Y. 2008. Power, space, and ethnic identity: politics, the culture of the nation-state in Thai society. Bangkok: Sirindhorn Anthropology Center (Public Organization).

Surasonthi, K. 2005. Communication knowledge. Bangkok: Aksorn Pittaya.

Trakuldee, C. 1999. Guidelines for tourism development in Lamphun Province. Chiang Mai University. 